\title{
Prof. William C. Koller, MD, PhD (1945-2005)
}

The editors and members of the editorial board of Neuroepidemiology are saddened by the unexpected death of Prof. William Koller on 3 October 2005 in Chapel Hill, N.C. Bill Koller was a long-time friend and an active member of the editorial board of Neuroepidemiology for many years. He was always generous with his time and expertise in the review of manuscripts on Parkinson's disease, essential tremor, and movement disorders. As a rule, his careful reviews always offered the authors points of improvement based on his encyclopedic knowledge of these topics. He published more than 270 peerreviewed articles, 160 review papers and multiple books. In 1999 he became National Research Director for the National Parkinson Foundation; he was also Fellow of the American Academy of Neurology, the Movement Disorders Society, the Parkinson Study Group (1996-1999), President of WE MOVE (2001-2002), founding member of the Tremor Research Group, and the International Tremor Foundation. We convey our sympathy to his wife and sons.

Gustavo C. Román, MD Editor-in-Chief

(C) 2006 S. Karger AG, Basel

$0251-5350 / 06 / 0263-0176 \$ 23.50 / 0$

Accessible online at: www.karger.com/ned 